Borneo Journal of Sciences \& Technology, Volume (3), Issue (1), Pages: 61-65

DOI: http://doi.org/10.3570/bjost.2021.3.1-09

e-ISSN: 2672-7439

(C) 2018, UCTS Publisher.

Submitted: $17^{\text {th }}$ October $2020 \quad$ Accepted: $29^{\text {th }}$ November $2020 \quad$ Published: $31^{\text {st }}$ January 2021

\title{
Land Cover Change Detection in Kuching, Malaysia Using Satellite Imagery.
}

\author{
Ricky Anak Kemarau and Oliver Valentine Eboy
}

Geography Program, Faculties of Humanities, Art and Heritage, University Malaysia Sabah (UMS), 88400 Kota Kinabalu, Sabah, Malaysia.

\begin{abstract}
Land cover maps symbolize integrated information about the universal status of specific areas. Land cover critical in many purposes as the baseline in the planning and monitoring of each development of a place in creating a balance of development between the environment and humans. The objective of the study to detect the land cover change in Kuching for 46 years which between 1972, 1988, and 2018. Literature reviews concrete utilized on Landsat 2,3,4,5,6,7 and 8 at studies in generating of landcover maps. The still limited studies done with Landsat 1, which start operating in July 1972 and stop operating in January 1978. To achieve the objectives of this study, the first step is to do pre-processes such as radiometric correction, atmospheric correction and geometric correction. The second step is to carry out the process of classifying the ground cover for three years of data for the manufacture of ground cover maps. To measure and confirm the accuracy of the ground cover map, this study uses Google Earth map and land use from the Department of Survey and Mapping Malaysia. Statistical kappa tests were used to determine the accuracy of land cover maps from satellites with 95 percent accuracy using 100 random sample points. The next step with GIS applied Change Detection to generated map land cover change in this study. Land cover maps are important land use planning and land use regulation in an effort to avoid land use conflicts. Land cover and land use plans are implemented through land allocation and the use of rules and regulations, such as zone regulations. Management consulting firms and non-governmental organizations often try to influence this rule before it is codified.
\end{abstract}

Keywords: Remote Sensing, GIS, Land Cover Change, Landsat 1 MSS

\section{INTRODUCTION}

Accordingly to Krishna et al. [1] the and cover change occurring fast in South and Southeast Asia countries, namely India, Nepal, Bhutan, Indonesia, Malaysia, Singapore, Thailand, Vietnam, and Cambodia. The rapid development generally associated with increasing our population, urban expansion, and competing for the need for land. Recording and documentation of land cover and correlated impacts gain significance in Malaysia as the products can be valuable for advising policymakers and enhanced land management. The traditional methods, such as fieldwork, interpreting old maps, and literature reviews, are not sufficient cause of time-consuming, expensive, and human resources costs. The remote data sensing can offer data in multitemporal, synoptic, and repetitive. The land cover changes are significant to monitoring, supervising, and document the land cover impact.

Hence, remote sensing provides a practical and excellent tool to map and calculate the land cover change on a different scale, time, and place $[2 ; 3 ; 4 ; 5]$. The literature reviews have concreted on land cover change detection by using various models, methods, and satellite images, namely [6] utilized normalized difference vegetation index (NDVI), principal component analysis (PCA). Nutini et al., [7] working multi-temporal analysis and Landsat images; Kim et al. [8] utilized Landsat images; Mayes et al. [9] furthered from Landsat 5-8 data and linear spectral mixture analysis; Choudhary and Pathak [10] investigated landuse change detection using Landsat imageries of TM. ETM and OLI; Leite et al. [11] applied Landsat 5/TM images and geographical objects; Sidhu et al. [12] utilized the Google Earth for land cover change mapping; Zoungrana et al. [13] utilized MODIS satellite imagery for application of land cover change detection. However, most of them use data Landsat 5 TM, Landsat ETM, and Landsat 8. The still used Landsat 1 MSS. The Landsat 1 MSS, which the policymakers of Landsat generation, can offer that data from July 1972 until January 1978. The long trend of

Corresponding Author: Ricky Anak Kemarau, University Malaysia Sabah (UMS)

Email: ricky.geo2005@gmail.com 
Land Cover Change Detection in Kuching, Malaysia Using Satellite Imagery.

land cover information vital for policymakers and decision-makers in order to monitor the capital of Sarawak. The study objective of the study is to quantify the change in the land cover between 1972 and 1988 and 1988 and 2018

\section{MATERIALS AND METHODS}

\section{Study area}

Mapping of land cover changes in Kuching City is critical because there is still a lack of research in studying land use changes and land cover in cities in Sarawak, especially Kuching. In addition, the population of Kuching City is increasing every year (Malaysia Statistics Department, 2010).

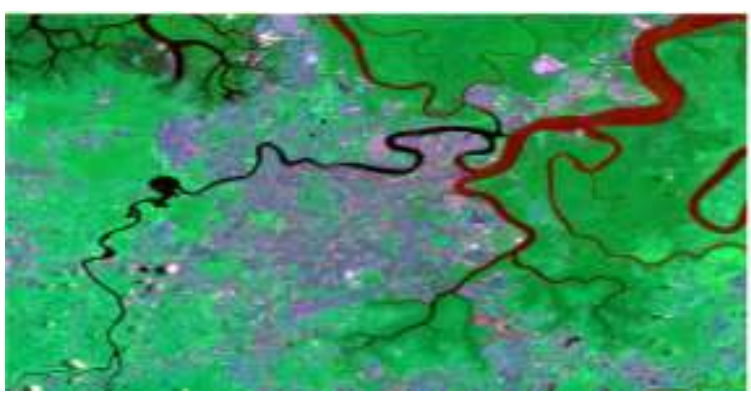

Figure 1: Location of the study area.

The selection of all three data is due to the fact that there is no cloud coverage which the Landsat satellite wavelength cannot penetrate the cloud. in addition, Landsat data in 1972 was the most quality and earliest satellite image in the history of the use of satellites in mapping. Table 1 shows the data information used. Tables 2,3 and 4 show the wavelength information used in the mapping.

Table 1: Information of dataset

\begin{tabular}{|c|c|}
\hline Sensor & $\begin{array}{c}\text { Data } \\
\text { Acquisition }\end{array}$ \\
\hline $\begin{array}{c}\text { Landsat 1 Multispectral Scanner } \\
\text { (MSS) }\end{array}$ & $\begin{array}{c}\text { 14 September } \\
1972\end{array}$ \\
\hline $\begin{array}{c}\text { Landsat 5 Thematic Mapper (TM) } \\
\text { Landsat 8 Operational Land } \\
\text { Imager (OLI) and Thermal } \\
\text { Infrared Sensor (TIRS) }\end{array}$ & 15 May 2018 \\
\hline
\end{tabular}

Table 2: Information of Landsat 1,2,3,4,5 MSS

\begin{tabular}{|c|c|c|c|}
\hline $\begin{array}{c}\text { Landsat 1- } \\
3 \\
\text { MSS }\end{array}$ & $\begin{array}{c}\text { Landsat 4- } \\
5\end{array}$ & $\begin{array}{c}\text { Wavelength } \\
\text { (micrometers) }\end{array}$ & $\begin{array}{c}\text { Resolution } \\
\text { (meters) }\end{array}$ \\
\hline Band 4 & Band 1 & $0.5-0.6$ & 60 \\
\hline Band 5 & Band 2 & $0.7-0.6$ & 60 \\
\hline Band 6 & Band 3 & $0.7-0.8$ & 60 \\
\hline Band 7 & Band 4 & $0.8-1.1$ & 60 \\
\hline
\end{tabular}

Table 3: Information of Landsat 5 TM

\begin{tabular}{|c|c|c|}
\hline $\begin{array}{c}\text { Landsat 4-5 } \\
\text { TM }\end{array}$ & $\begin{array}{c}\text { Wavelength } \\
\text { (micrometers) }\end{array}$ & $\begin{array}{c}\text { Resolution } \\
\text { (meters) }\end{array}$ \\
\hline Band 1 & $0.43-0.45$ & 30 \\
\hline Band 2 & $0.45-0.61$ & 30 \\
\hline Band 3 & $0.53-0.59$ & 30 \\
\hline Band 4 & $0.64-0.67$ & 30 \\
\hline Band 5 & $0.85-0.88$ & 30 \\
\hline Band 6 & $1.57-1.65$ & 60 \\
\hline Band 7 & $2.11-2.29$ & 30 \\
\hline Band 8 & $0.50-0.68$ & 15 \\
\hline
\end{tabular}

Table 4: Information for Landsat 8 OLI and TIRS

\begin{tabular}{|c|c|c|}
\hline $\begin{array}{c}\text { Landsat 8 } \\
\text { OLI and } \\
\text { TIRS }\end{array}$ & $\begin{array}{c}\text { Wavelength } \\
\text { (micrometers) }\end{array}$ & $\begin{array}{c}\text { Resolution } \\
\text { (meters) }\end{array}$ \\
\hline $\begin{array}{c}\text { Band 1 - } \\
\text { Coastal } \\
\text { aerosol }\end{array}$ & $0.45-0.52$ & 30 \\
\hline Band 2 & $0.52-0.60$ & 30 \\
\hline Band 3 & $0.63-0.69$ & 30 \\
\hline Band 4 & $0.76-0.90$ & 30 \\
\hline Band 5 & $1.55-1.75$ & 30 \\
\hline Band 6 & $10.40-12.50$ & 60 \\
\hline Band 7 & $2.08-2.35$ & 30 \\
\hline $\begin{array}{c}\text { Band 8 - } \\
\text { panchromatic }\end{array}$ & $0.50-0.68$ & 15 \\
\hline $\begin{array}{c}\text { Band 9 - } \\
\text { cirrus }\end{array}$ & $1.36-1.38$ & 30 \\
\hline $\begin{array}{c}\text { Band 10 } \\
\text { Thermal } \\
\text { Infrared 1 }\end{array}$ & $10.6-11.19$ & 100 \\
\hline $\begin{array}{c}\text { Band 11 } \\
\text { Thermal } \\
\text { Infrared 2 }\end{array}$ & $11.50-12.51$ & 100 \\
\hline
\end{tabular}

In the first of the stage, authors applied preprocessing, namely atmosphere correction and radiometric correction, to improve our quality of data remote sensing for 3 data images. In the second of the stage, authors applied Iso Cluster Unsupervised for procedures of the land cover map for the years 1988, and 2018. For Landsat 1 MSS at the year 1972 required aouthrs do principal component classification. Iso Cluster unsupervised failed to generate the best result. The because of spectral at Landsat 1 MSS give a 
different response to Iso unsupervised classification. The next step required the calculated area of every land cover at attribute data at ArcGIS, the area of land cover calculated and displayed in the graph. The accuracy assessment of map land cover 1972, 1988, and 2019 done with the time series analysis at google earth, as shown in the figure 2.
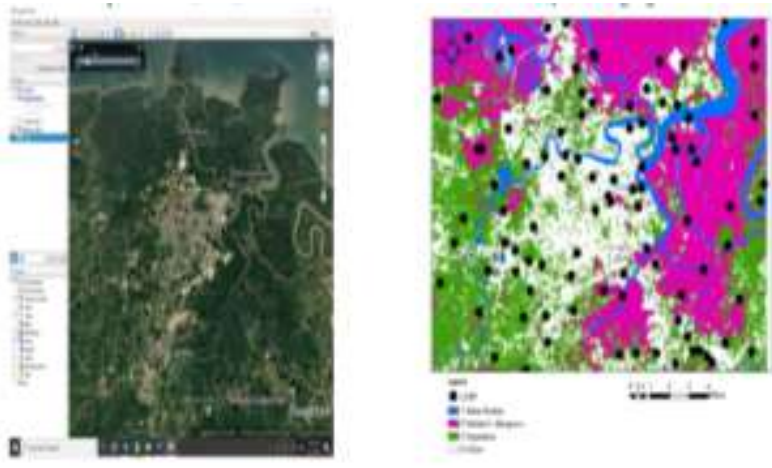

Figure 2: A random distribution of point samples. Source: Authors

On the right side of the land cover map and on the left is google earth which is used as a guide in calibrating the accuracy of the land cover map in 1988 for example.

Figure: Location of Sample Point at Google earth and GIS.

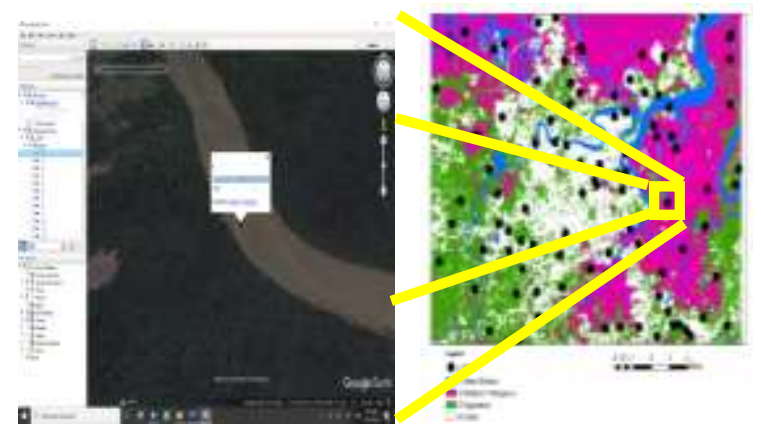

Figure 3 shows the step 2 accuracy assessment for point 1 , which shows directly to the location on google earth (left) and ArcGIS (Right).

Source: Authors

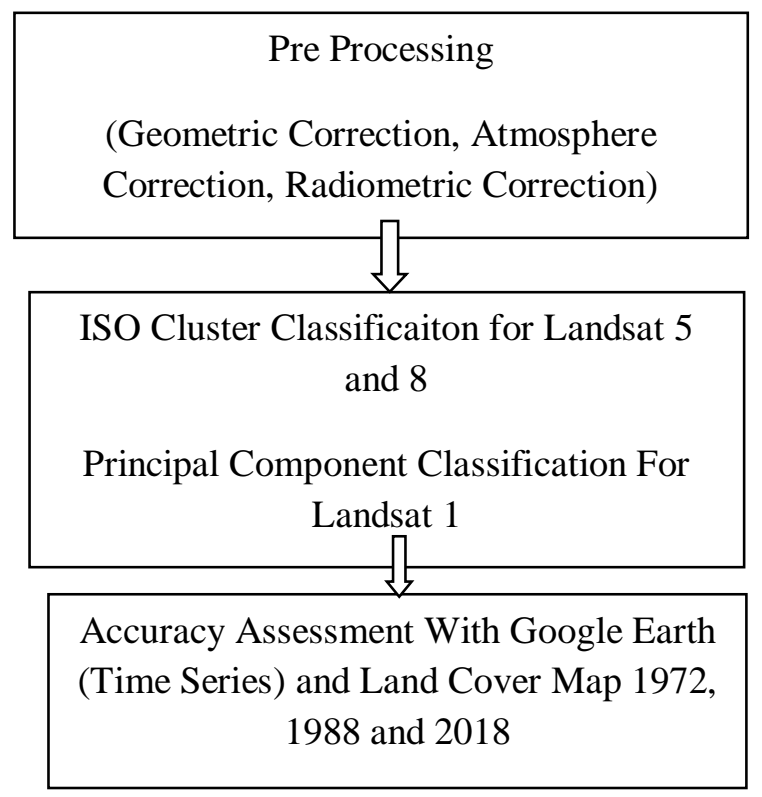

Figure 4: Flow Methodology Source: Authors

\section{RESULT AND DISCUSSION}
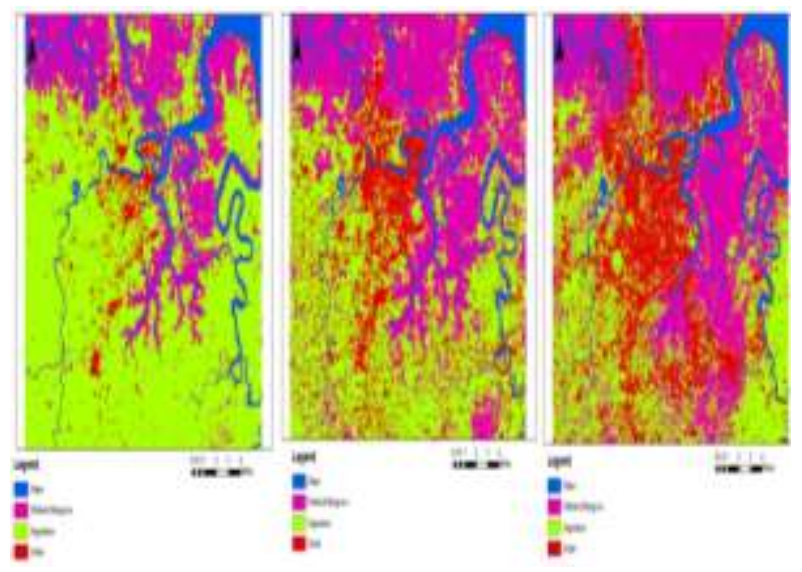

Figure 5: Map land cover in Kuching for the year 1972 (left), 1988 (center) and 2018 (right).

Source: Authors

Figure 5 shows the land cover maps for 1972, 1988 and 2018. Referring to the three maps above it is clear that there is a significant change for each of the three years. Development activities are municipalities involving housing settlements, industrial areas, business areas and administrative areas. This urbanization activity caused the change of land cover from vegetation to built up i.e. the city. These urbanization activities expanded from the city center to the suburbs and the countryside. In addition, this study also found that wetland area reclamation activities to urban activities such as industrial and port activities. 


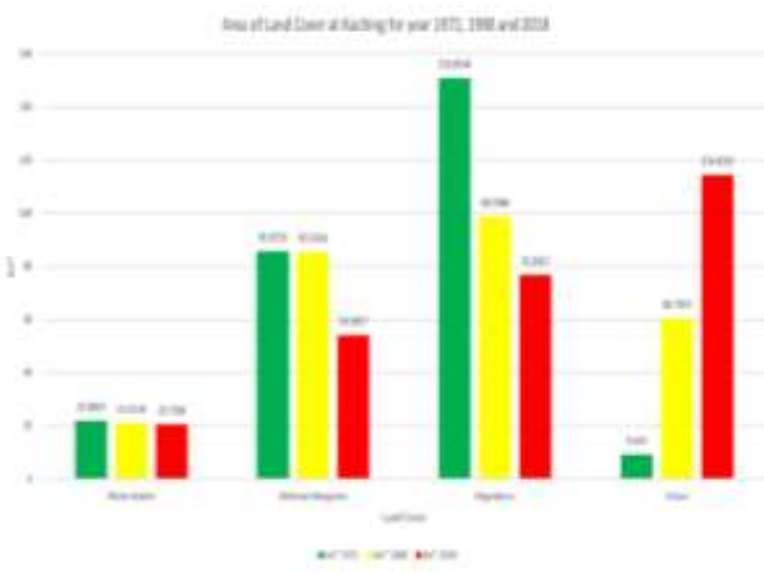

Figure 6: The areas of land cover at Kuching for the years 1972, 1988, and 2018.

\section{Source: Authors}

In 1972 the largest landfill vegetation area with a value of $150,085 \mathrm{~km}^{2}$, the second wetland mangrove with $85.59 \mathrm{~km} 85.87 \mathrm{~km}^{2}$, the third water body with 21.88 , and the last urban area with $9.243 \mathrm{~km} \mathrm{~km}^{2}$. In 1988 , the largest land cover was the vegetation cover of $98.59 \mathrm{~km}^{2}, 85.59 \mathrm{~km}^{2}$ second, and the third urban area replaced the water body with $60.72 \mathrm{~km}^{2}$ and the water body with an area of $21.1535 \mathrm{~km}^{2}$. In 2018, the largest area is the urban area with $114,416 \mathrm{~km}^{2}$, the second vegetation area with $76.82 \mathrm{~km}^{2}$, the third wetland mangrove with $\mathrm{km}^{2}$ and the last $20.73 \mathrm{~km}^{2}$. This clearly shows that there was a major change between 1972 and 2018 where most of the area changed from plant to urban area.

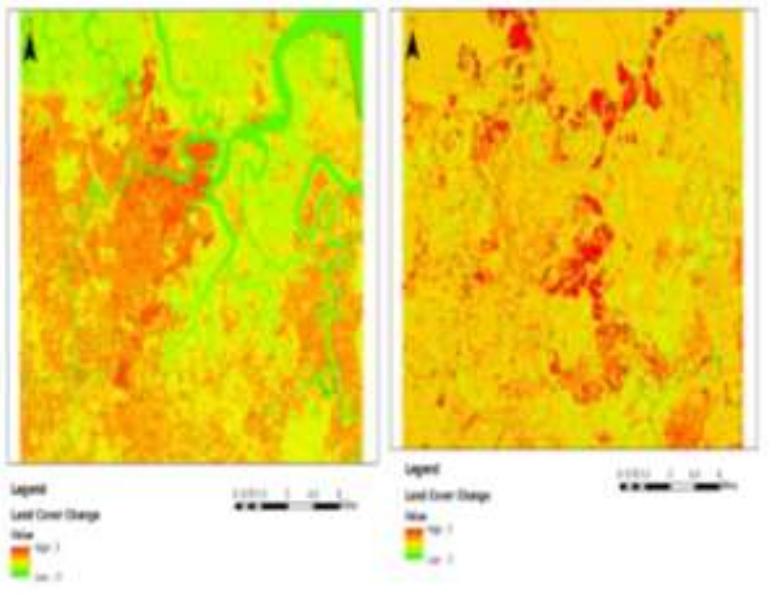

Figure 7. The land cover change between 1972 with 1988 (left) and 1988 with 2018 (right).

Source: Authors

The indicator shows between 3 maximum and negative changes -3 indicates no change between selected years.
During the 46 different years between 1972 and 2018, Kuching experienced rapid urban development. The type of land use of municipal activities covers an increase of $105.16 \mathrm{~km}^{2}$. Urban development activities cause the destruction of forest areas, mangrove swamps. This caused the total wetland to decrease by 31.52 between 1988 and 2018 and $0.279 \mathrm{~km}^{2}$ for 1972 and 1988.

The most significant thing occurred between 1988 and 2018, most of the urban concrete development in wetlands compared to vegetation in 1972 and 1988. For example, the development surrounded by the Sarawak River, Pending Industrial, Demak, Samajaya Industrial. The second example, administrative areas such as Petra Jaya and settlements in Tabuan, Stutong, Matang, Demak, and South Kuching to meet the demand of the population increased between 46 years. The watershed area decreased due to the reclamation to the Port of Samajaya which was built and upgraded the Kuching Port area.

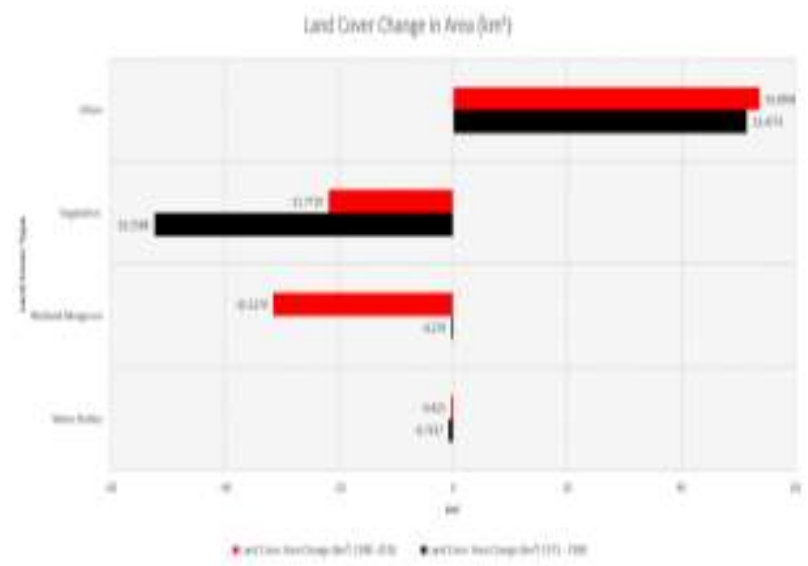

Figure 8: The cover change between 1972 with 1988 and 1988 with 2018.

The most significant change between land cover 1972 with 1988 is vegetation land cover type with a decrease $52.25 \mathrm{~km}^{2}$. in between the year 1988 with 2018, the most massive area change in urban areas with value $53.69 \mathrm{~km}$. Between the years 1972 and 1988, the second biggest land cover change is an urban area with an increase of $51.37 \mathrm{~km}^{2}$. However, between the years 1988 and 2018, the second significant change is wetland mangrove, with a decrease of $31.52 \mathrm{~km}^{2}$. The water bodies cover type is third-largest change with a decrease of $0.731 \mathrm{~km}^{2}$ between the years 1972 and 1988. However, in year land cover change between 1988 and 2018, shows the vegetation experience decrease $31.52 \mathrm{~km}^{2}$. Between the years 1972 and 1988 , wetland mangrove with a decrease of $0.27 \mathrm{~km}^{2}$ and water bodies between the years 1988 and 2018. 
Land Cover Change Detection in Kuching, Malaysia Using Satellite Imagery.

\section{CONCLUSION}

The results of this study clearly found that the development of urbanization activities changed the landscape over 46 years, namely the transformation from vegetation to urban areas. This study found that ISO Cluster Classification can produce ground cover maps for 1988, and 2018, namely for Landsat 5 TM and 8 OLI TIR satellites. This method is not suitable for Landsat 1 satellites. Principal Component classification is suitable in Landsat 1 data processing for the production of land cover maps. This is because of the different spectrum between Landsat 1 MSS, Landsat 5T $\mathrm{M}$, and Landsat. Through visual interpretation with google google assist in the same year. All ground cover produced is acknowledged and corrected. Verifying ground cover with Google Earth provides the author with knowledge of the study area. The results show that the most significant land cover change is urban areas, which increased by $104.13 \mathrm{~km}^{2}$. The study found that between 1972 and 1988 most of the vegetation cover was replaced by urban areas with a decrease of 25.22 $\mathrm{km}^{2}$. in 1988 to 2018, wetlands were transformed into urban areas with a total loss of $31.52 \mathrm{~km}^{2}$. The use of Landsat $1 \mathrm{MSS}$ in the data to study soil cover changes is corrected and accurate. Monitoring, supervising and documenting significant land cover changes for policy makers and urban planning understand the impact of land closure on the environment and society.

\section{ACKNOWLEDGMENT}

We thank NASA for access to their resources of Landsat generation data.

\section{REFERENCES}

[1] Krishna V, Andreas H, Garik G. \& Chris J. (2019) Remote sensing of land use/cover changes in South and Southeast Asian Countries, International Journal of Digital Earth, 12:10, 1099-1102, DOI: 10.1080/17538947.2019.1654274

[2] Moser G, Serpico SB, \& Benediktsson JA. Landcover mapping by Markov modeling of spatialcontextual information in very high-resolution remote sensing images. Proceedings of the IEEE. 2013;101(3):631651.

[3] Amici V, Marcantonio M, La Porta N and Rocchini D. A Multi-temporal approach in MaxEnt modeling: A new frontier for land use/land cover change detection. Ecological Informatics 2017;40:40-49.
[4] Hasmadi M, Pakhriazad H, and Shahrin M. Evaluating supervised and unsupervised techniques for land cover mapping using remote sensing data. Geografia-Malaysian Journal of Society and Space. 2017;5(1).

[5] Wu K, Du Q, Wang Y, and Yang Y. Supervised sub-pixel mapping for change detection from remotely sensed images with different resolutions. Remote Sensing. 2017;9(3):284.

[6] Shahabi H, Ahmad BB, Mokhtari MH, and Zadeh MA. Detection of urban irregular development and green space destruction using normalized difference vegetation index (NDVI), principal component analysis (PCA), and post-classification methods: a case study of Saqqez City. International Journal of Physical Sciences. 2012;7(17):2587-2595.

[7] Nutini F, Boschetti M, Brivio P, Bocchi S, and Antoninetti M. Land-use and land-cover change detection in a semi-arid area of Niger using multitemporal analysis of Landsat images. International journal of remote sensing. 2013;34(13):4769-4790.

[8] Kim D-H, Sexton JO, Noojipady P, Huang C, Anand A, Channan S, Feng M, and Townshend JR. Global, Landsat-based forest-cover change from 1990 to 2000. Remote Sensing of Environment. 2014;155:178-193.

[9] Mayes MT, Mustard JF, and Melillo JM. Forest cover change in Miombo Woodlands: modeling land cover of African dry tropical forests with linear spectral mixture analysis. Remote Sensing of Environment. 2015;165:203-215.

[10] Choudhary R and Pathak D. Land use/land cover change detection through temporal imageries and its implications in water-induced disaster in Triyuga watershed, east Nepal. Journal of Nepal Geological Society. 2016;51:49-54.

[11] Leite Lr, Carvalho Lmtd, and Silva FMD. Change detection in forests and savannas using statistical analysis based on geographical objects. Boletim de Ciências Geodésicas. 2017;23(2):284-295.

[12] Sidhu N, Pebesma E, and Câmara G. Using Google Earth Engine to detect land cover change: Singapore as a use case. European Journal of Remote Sensing. 2018;51(1):486-500.

[13]Zoungrana BJ, Conrad C, Thiel M, Amekudzi LK, and Da ED. MODIS NDVI trends and fractional land cover change for improved assessments of vegetation degradation in Burkina Faso, West Africa. Journal of Arid Environments. 2018;153:6675 . 